\title{
The influence of titanium and iron oxides on the coloring and friability of the blue fired aluminum oxide as an abrasive material
}

\section{(Influência da titânia e óxido de ferro na coloração e friabilidade do óxido de alumínio blue fired como material abrasivo)}

\author{
E. R. Passos ${ }^{1}$, J. A. Rodrigues ${ }^{2}$ \\ ${ }^{1}$ Elfusa Geral de Eletrofusão Ltda., Rua Júlio Michelazzo, 501, Vila Nossa Senhora de Fátima, S. João \\ da Boa Vista, SP, Brasil 13872-900 \\ ${ }^{2}$ GEMM, DEMa, UFSCar, Rod. Washington Luiz, km 235, S. Carlos, SP, Brasil 13565-905 \\ edmilson.passos@elfusa.com.br, josear@ufscar.br
}

\begin{abstract}
The quality of abrasive grains is crucial to increase the lifespan of roughing, polishing and cutting tools. The purpose of the work herein was to evaluate the variables of the blue fired aluminum oxide heat treatment process. This heat treatment process improves the physical properties of the brown fused aluminum oxide and results in a blue coloring, which uniquely identifies it within the abrasives industry. The work herein includes information beginning with the electro-fusion process of bauxite (the manufacturing of the brown fused aluminum oxide) to the Blue Fired process. It also compares the fracture resistance index between these materials. This index is the inverse of the friability. Besides the content of titanium and iron oxides, process variables such as time, temperature and atmospheric conditions are important to monitor in order to reach standard requirements. Experimental evidence measuring these parameters is presented in the article herein. The blue coloring of this aluminum oxide is explained by the optical phenomena of electron transition, and not by the formation of aluminum titanate, as some technical literature has stated. Furthermore, it was proved that the coloring of blue fired material should not be used exclusively as an indicator of the optimal abrasive characteristics of this class of aluminum oxide.
\end{abstract}

Keywords: abrasives, brown fused alumina, blue fired fused aluminum oxide, titanium oxide, iron oxide, fracture resistance index.

Resumo

A qualidade dos grãos abrasivos é fundamental para o aumento da vida útil das ferramentas de desbaste, polimento e corte. Nesse contexto, o presente trabalho teve como objetivo avaliar as variáveis de tratamento térmico do óxido de alumínio eletrofundido marrom na obtenção do óxido de alumínio "blue fired". Este é um grão abrasivo com melhores propriedades fisicas, em relação ao óxido de aluminio eletrofundido marrom e que apresenta uma coloração azulada, característica essa exigida pelo mercado de abrasivos. Desta forma, este trabalho aborda o processo de eletrofusão da bauxita até a obtenção do "blue fired", assim como faz uma comparação do indice de resistência à fratura deste material com aquele dos óxidos de aluminio eletrofundido marrom convencionais. Esse indice se relaciona com o recíproco da friabilidade. Além dos teores dos óxidos de titânio e de ferro, as variáveis tempo, temperatura e atmosfera, aos quais o material é submetido, são parâmetros fundamentais a serem controlados a fim de se obter um grão abrasivo dentro dos padrões exigidos, como foi comprovado experimentalmente neste trabalho. A coloração da alumina eletrofundida é justificada por fenômenos óticos de transição eletrônica e não pela formação da fase titanato de alumínio, como algumas explicações encontradas na literatura técnica afirmam. Além disso, ficou demonstrado que essa coloração não deve ser utilizada como indicativo das características abrasivas ótimas desta classe de óxido de alumínio.

Palavras-chave: abrasivos, óxido de alumínio marrom, óxido de alumínio blue fired, óxido de titânio, óxido de ferro, índice de resistência a fratura.

\section{INTRODUCTION}

Titania greatly affects the abrasive properties of brown fused alumina. This material, which varies in terms of titania content, may be commercialized after being classified into different particle sizes. In addition, this material may have its abrasive properties optimized according to its titania content. When heat-treated under controlled time, temperature and atmospheric conditions, the brown fused alumina turns blue and is therefore named blue fired alumina. In order to better understand the influence of titania and the heat treatment process on the brown fused alumina, Elfusa Geral de Eletrofusão, a manufacturer of electro-fused alumina, has encouraged this work, which focused on producing and characterizing the blue fired alumina. Based on the present work, it was possible to conclude that controlling the process variables of time, temperature and atmospheric conditions are crucial for the production of blue fired alumina. The blue 
coloring of this material required by the market is justified by the optical phenomena of electronic transition; and not by the aluminum titanate phase, as it has been reported by some other technical papers.

Types of brown fused alumina: synthetic abrasive grains may be classified according to their chemical composition and particle size after comminution or granulometric characterization. As chemical composition, size and particle shape change in the material, mechanical properties of the abrasives will be influenced [1]. The production process of fused alumina starts by homogenizing raw materials in proportions, which are pre-established according to the specifics of the particular product to be made. Following that, the material is submitted to the electro-fusion process, cooling, crushing, and then taken to the roll grinders. After this stage, the material follows on to the sieves, for granulometric classification. Because some of these stages are of high-impact and the material consists of electro-fused ceramic, the comminution process generates large fractures, resulting in sharp, anisotropic and irregularly-shaped particles. In regards to the chemical composition, the classification of brown fused alumina is based on the titania $\left(\mathrm{TiO}_{2}\right)$ content, being divided in: low titania or high-purity (approximately $1.5 \mathrm{wt} \%$ of $\mathrm{TiO}_{2}$ ), and high titania or low-purity (approximately $2.5 \mathrm{wt} \%$ of $\mathrm{TiO}_{2}$ ). A technical explanation for this distinction is that the high-purity material (low $\mathrm{TiO}_{2}$ ) presents lower friability than the white fused alumina, but higher than the brown fused alumina with high titania. Another important abrasive property of the brown fused alumina presenting low content of $\mathrm{TiO}_{2}$ is its high capability of edge replacement of its particles as they are fractured. This is an important feature for the abrasives. On the other hand, the material of lower purity (high $\mathrm{TiO}_{2}$ ) presents higher mechanical strength [2]. In the case of the high-titania alumina, a titania based slag is concentrated in its grain boundaries, which gives a certain grade of hardness to the aggregate. On the other hand, in the low-titania alumina, the slag is more isolated and is distributed along with the crystals of the aggregate. In this case, the presence of titania is not so effective. Consequently, titania will not affect the mechanical properties of the corundum crystals, which will be more friable [3]. The slag consists basically of silica and contains microcrystalline impurities. It presents a composition similar to that of a mullite, being composed of silica, alumina and titania. Sometimes it is possible to detect mullite crystals in it. The microcrystalline impurities found in the slag may also contain magnesia and aluminum di-titanate. Alumina also can be present not only as a-alumina, but also as an amorphous phase [3].

Electro-fused abrasive grains production system: in the production of brown fused alumina, raw bauxite is the starting material used for the production of abrasive grains based on alumina. Bauxite is from 70 to $85 \mathrm{wt} \%$ composed of alumina under the form of gibbsite $\mathrm{Al}(\mathrm{OH})_{3}$, boehmite $\gamma-\mathrm{AlO}(\mathrm{OH})$ and diaspore $\alpha-\mathrm{AlO}(\mathrm{OH})$ minerals. Iron oxide, clay, silica and titanium dioxide are among its major impurities. To begin the production of brown fused alumina, it is necessary to perform the mixture and homogenization of bauxite with coke, titania and iron chips, forming a group of abrasive products containing controlled quantities of up to $4 \mathrm{wt} \%$ of titanium dioxide. During the fusion process, it is necessary to control the percentage of certain oxides because they directly affect the final material's physical properties. Such control is determined by adding reducing agents during fusion, through a pre-defined stoichiometry of the mixture to be melted. It is also interesting to take advantage of all possible metallic alloys generated during the process. Thus, the previously mentioned addition of iron chips is necessary to guarantee the high magnetic content of the Fe-Si alloy to be able to separate the fused alumina from the Fe-Si alloy. The most significant reduction reactions (Equations $\mathrm{A}, \mathrm{B}$ and $\mathrm{C}$ ) during the fusion of brown electro-fused alumina are [4]:

$$
\begin{aligned}
& \mathrm{Fe}_{2} \mathrm{O}_{3}+3 \mathrm{C} \rightarrow 2 \mathrm{Fe}+3 \mathrm{CO} \\
& \mathrm{SiO}_{2}+2 \mathrm{C} \rightarrow \mathrm{Si}+2 \mathrm{CO} \\
& \mathrm{TiO}_{2}+2 \mathrm{C} \rightarrow \mathrm{Ti}+2 \mathrm{CO}
\end{aligned}
$$

Blue fired fused aluminum oxide: Blue Fired material is a type of brown fused alumina presenting equal proportions of $\mathrm{Al}_{2} \mathrm{O}_{3}$ to the regular brown fused alumina, or semi-friable alumina. This material is ground and particle size classified, and then submitted for heat treatment, giving the material its blue coloring. This product is known as blue fired fused alumina in the abrasive industry. One important characteristic of this material is that it presents an increased lifespan in comparison to brown electro-fused grains (those that did not go through a specific heat treatment). Some technical reports [3-5] have shown that when corundum is treated at an approximate temperature of $1280^{\circ} \mathrm{C}$, for $10 \mathrm{~h}$, the aluminum titanate phase, $\mathrm{Al}_{2} \mathrm{TiO}_{5}$ [6], appears, giving the material its blue coloring. However, the present work has proved that $\mathrm{Al}_{2} \mathrm{TiO}_{5}$ is not the determining factor for the blue coloring of the blue fired fused alumina.

\section{MATERIALS AND METHODS}

Materials: the samples were prepared from grains presenting a particle size designated as P60 (Table I) and obtained according to the ANSI (American National Standards Institute) B74.18 standard [7], using a Ro-Tap system from Solotest and sieves from Haver \& Boecher. The special semi-friable brown fused alumina of medium titania content, designated herein as ASFE, was used, as well as the semi-friable brown fused alumina of low titania content, designated as ASF. Lastly, the regular brown fused alumina of high titania content was also used, being designated as AR. The basic chemical compositions of these three materials are shown in Table II.

Sample preparation: the samples collected from the Elfusa production line of brown fused alumina were analyzed via X-ray fluorescence, using a Philips X'Pert, 
Table I - Particle size specification for the grain P60 according to the ANSI B7418 standard.

[Tabela I - Especificação granulométrica para o grão P60 de acordo com a norma ANSI B7418.]

\begin{tabular}{lccc}
\hline Mesh $(\mathrm{mm})$ & $\begin{array}{c}\text { Minimum } \\
(\mathrm{wt} \%)\end{array}$ & $\begin{array}{c}\text { Results } \\
(\mathrm{wt} \%)\end{array}$ & $\begin{array}{c}\text { Maximum } \\
(\mathrm{wt} \%)\end{array}$ \\
\hline $35(0.5)$ & 0 & 0 & 0 \\
$+45(+0.355)$ & 0 & 2 & 4 \\
$+50(+0.297)$ & 12 & 23 & 27 \\
$+60(+0.250)$ & 55 & 68 & 81 \\
$+70(+0.212)$ & 90 & 96 & 100 \\
$-70(-0.212)$ & 0 & 4 & 10 \\
\hline
\end{tabular}

Table II - Basic chemical composition of special semi-friable (ASFE), semi-friable (ASF), and regular brown fused alumina (AR), given in wt\%. "Others" include $\mathrm{CaO}, \mathrm{SiO}_{2}, \mathrm{ZrO}_{2}$ and $\mathrm{K}_{2} \mathrm{O}$.

[Tabela II - Composição química básica do semi-friável especial (ASFE), semi-friável (ASF) e óxido de alumínio fundido regular marrom (AR) em \%p. "Outros" incluem CaO, $\mathrm{SiO}_{2}, \mathrm{ZrO}_{2}$ e $\mathrm{K}_{2} \mathrm{O}$.]

\begin{tabular}{lccccc}
\hline $\begin{array}{l}\text { Type of } \\
\text { material }\end{array}$ & $\mathrm{Al}_{2} \mathrm{O}_{3}$ & $\mathrm{TiO}_{2}$ & $\mathrm{SiO}_{2}$ & $\mathrm{Fe}_{2} \mathrm{O}_{3}$ & Others \\
\hline ASFE & 97.40 & 1.68 & 0.54 & 0.11 & 0.27 \\
ASF & 97.64 & 1.43 & 0.53 & 0.12 & 0.28 \\
AR & 95.69 & 2.66 & 0.83 & 0.28 & 0.54 \\
\hline
\end{tabular}

and X-ray diffraction equipment also manufactured by Philips, Axios Max. This equipment was used to quantify the chemical composition and identify the phases present. After these characterizations, samples of the same grain size were submitted to heat treatments in a furnace, Jung LF7014, for $14 \mathrm{~h}$, at temperatures ranging from 1100 to $1400{ }^{\circ} \mathrm{C}$, in increments of $50{ }^{\circ} \mathrm{C}$. The criteria evaluated for this work consisted of the friability value and material's coloring after the brown fused alumina was heat-treated. After the ideal temperature was established (in terms of friability and coloring), the selected samples were submitted to heat treatment varying the time, which ranged from 7 , to 14 , to $21 \mathrm{~h}$. After optimizing the time and temperature, once again considering the friability and coloring aspects, it was analyzed for the influence of oxygen. For that, it was necessary to use an oxidizing atmosphere (air), and an inert one (argon). Lastly, it was tested the effect of the basic chemical composition, in terms of iron oxide and titanium oxide.

Phase characterization using $X$-ray diffraction: this technique was used to assess the formation and presence of different phases, aiming to justify the color change of the brown fused alumina, which was treated at different temperatures, times and atmospheric conditions. The samples were milled in a tungsten carbide mill, AMEF-
AMP, until $99 \%$ of the material passed through a 325 mesh sieve. The operational conditions of diffraction were: $\mathrm{Cu}-\mathrm{K}_{\alpha}$ radiation, employing a $\mathrm{Ni}$ filter, $40 \mathrm{kV}$ of voltage and current of $40 \mathrm{~mA}$. The employed measurement procedure had $2 \theta$ ranging from 5 to $80^{\circ}$, at a speed of $2^{\circ} \mathrm{min}^{-1}$.

Observing the particles'coloring: an optical stereoscope, Motic K400, captured the images to be analyzed. Counting on the help of suitable devices, it is possible to obtain images with the perception of the dimensions of height, width, and depth. Considering the fact that abrasive grains are irregularly-shaped particles, the stereoscopic technique is adequate to visualize the superficial appearance of such material. Therefore, this technique was used to observe the coloring of brown fused alumina after heat treatments.

Normalized fracture resistance index: the fracture resistance index test, FRI, determines the percentage of particles that resist to fracture after they are submitted to milling. The higher the FRI value, the higher the mass of the material retained in a standard sieve and, therefore, the more resistant is the material. In that case, fewer particles are fractured, therefore the friability of the material is lower. To determine this property, the grains classified as P60 were submitted to a 10 min milling in a ball mill, according to the ANSI B74.8 standard [8]. After that, the grains passed through a standard sieve from Haver \& Boecher and the amount of material retained was measured. This sieve has a standard screen, pre-defined according to the size of the particle under analysis, a 70 mesh for the case of the P60 grains. For the FRI calculation, the following formula was applied (Equation D):

$\mathrm{FRI}=\left(\frac{\text { Weight of the sample retained after milling }}{\text { Initial weight of the sample }}\right) \times 100$

It is known, however, that the shape of the particles affects the FRI value of the material. Therefore, the particles with a larger number of faces present an inferior value to the index than the round particles, if considering the same values of initial particle size. To account for the particles' shape effect on the FRI, the formula below presents the normalized fracture resistance index (Equation E). This index is dimensionless.

$$
\mathrm{NFRI}=\left(\frac{\mathrm{FRI}}{100}\right) \times\left(\frac{\mathrm{D}_{\mathrm{r}}}{\mathrm{D}_{\mathrm{b}}}\right)
$$

in which $D_{b}$ is the bulk or volumetric density, given in $\mathrm{g} / \mathrm{cm}^{3}$ [9], and $\mathrm{D}_{\mathrm{r}}$ corresponds to the specific real mass of the grains [10]. The bulk density is given by the ratio between the mass of the particles and the known volume of a container to be filled. The specific mass, on the other hand, is the ratio between the dry weight of the grains and the volume of the solid part. This volume includes the solid part of the grains and the volume of the impermeable pores (considered, herein, as an integrating part of the volume of solids). 
The bulk density was determined using a standard of the Federation of the European Producers of Abrasives, FEPA 44-1:2006(en).

\section{RESULTS AND DISCUSSION}

When analyzing the normalized fracture resistance index, NFRI, for the three types of material (Fig. 1), it is possible to observe that this index increases up to a specific temperature, decreasing after that. To calculate the NFRI of different materials, it is presented in Table III the reference values of bulk density $\left(\mathrm{D}_{\mathrm{b}}\right)$ and real density $\left(\mathrm{D}_{\mathrm{r}}\right)$ for the different types of material that were not heat-treated. With the help of a stereomicroscope, it was possible to better assess the color of ASFE, ASF, and AR grains presenting P60 particle size. Fig. 2 compares the coloring of the grains that were not heat-treated to the grains heat-treated at 1250 and $1400{ }^{\circ} \mathrm{C}$ for $14 \mathrm{~h}$. Whilst the coloring of ASFE and AR grains turned into an intense blue at $1250{ }^{\circ} \mathrm{C}, \mathrm{ASF}$ had to reach a higher temperature to become blue, but not a very typical blue. It is important to note here that the content of $\mathrm{Fe}_{2} \mathrm{O}_{3}$ and $\mathrm{TiO}_{2}$ in ASF and ASFE

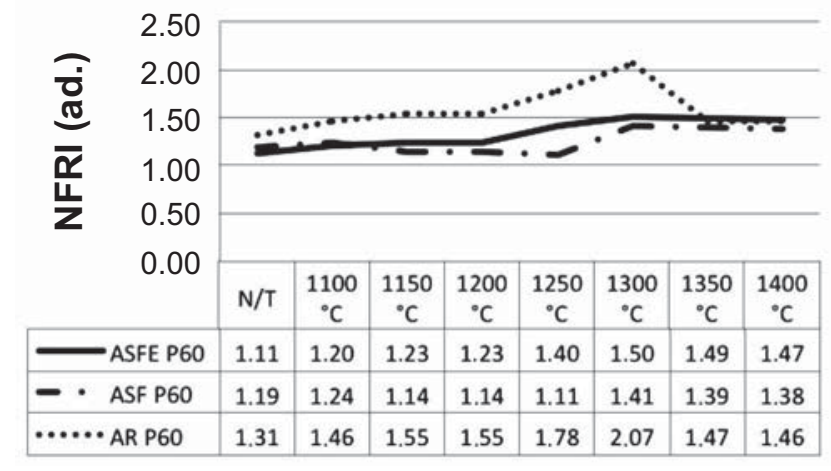

Figure 1: Results of normalized fracture resistance index, NFRI, of P60 grains for ASFE, ASF and AR after being exposed to different temperatures during $14 \mathrm{~h}$ of heat treatment. "N/T" means "non heat treated".

[Figura 1: Resultados do indice de resistência a fratura normalizado, NFRI, para os grãos P60 dos materiais ASFE, ASF e $A R$ após diferentes temperaturas de tratamento térmico, por $14 \mathrm{~h}$. "N/T" quer dizer "não tratado termicamente".]

Table III - Values of bulk density, $\mathrm{D}_{\mathrm{b}}$, and real density, $\mathrm{D}_{\mathrm{r}}$, for brown fused aluminas.

[Tabela III - Valor de densidade solta, $D_{b}$, e densidade real, $D$, dos óxidos de alumínio marrom.]

\begin{tabular}{lcc}
\hline Material & $\mathrm{Db}\left(\mathrm{g} / \mathrm{cm}^{3}\right)$ & $\operatorname{Dr}\left(\mathrm{g} / \mathrm{cm}^{3}\right)$ \\
\hline ASFE P60 & 1.82 & 4.01 \\
ASF P60 & 1.82 & 3.94 \\
AR P60 & 1.79 & 3.96 \\
\hline
\end{tabular}

(Table II) is lower than that of AR.

As an example, Fig. 3 presents the X-ray diffraction results for ASFE, samples without heat treatment, and for those treated at 1250 and $1400{ }^{\circ} \mathrm{C}$ (both for $14 \mathrm{~h}$ ). The identification
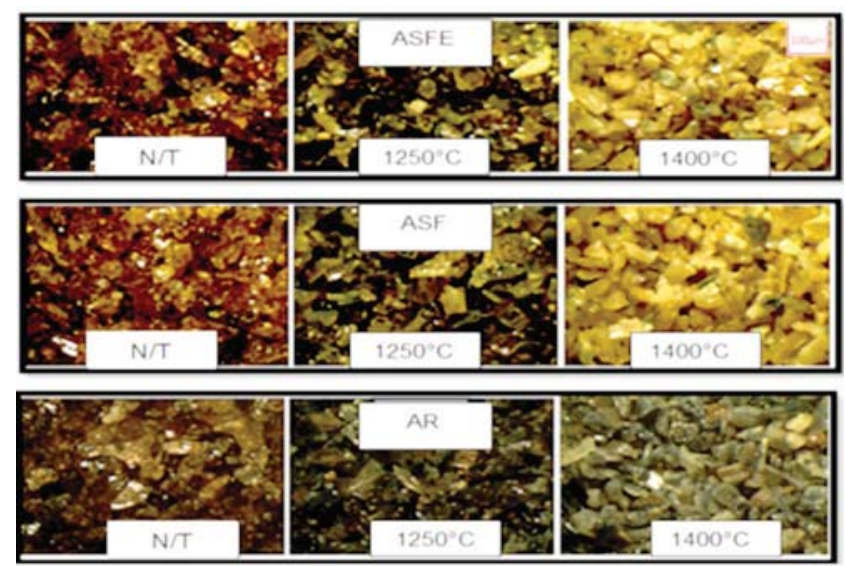

Figure 2: Images of ASFE, ASF and AR P60 grains treated at 1250 and $1400{ }^{\circ} \mathrm{C}$, for $14 \mathrm{~h}$. "N/T" means "non heat treated".

[Figura 2: Imagens dos grãos P60 de ASFE, ASF e AR tratados termicamente a 1250 e $1400{ }^{\circ} \mathrm{C}$, por $14 \mathrm{~h}$. "N/T" quer dizer "não tratado termicamente".]

of phases was difficult because the major phase, alumina (peak 1, as identified in Fig. 3), is greater than $95 \mathrm{wt} \%$, even when using the Rietveld technique. Nevertheless, during the heat treatment, it is possible to verify some small changes. The main event to be highlighted is the intensification of the rutile phase peak (peak 2, as identified in Fig. 3), for the ASFE sample treated at $1250{ }^{\circ} \mathrm{C}$, for $14 \mathrm{~h}$. Regarding the $\mathrm{Al}_{2} \mathrm{TiO}_{5}$ phase (peak 3, as identified in Fig. 3), there is no difference in the phase formation during the heat treatment. $\mathrm{CaFeSi}_{2} \mathrm{O}_{6}$ and $\mathrm{Ca}_{2} \mathrm{MgSiO}_{7}$ phases (peak 4, as identified in Fig. 3), on the other hand, also present an intensification, whilst the possible $\mathrm{Na}_{2} \mathrm{TiSiO}_{3}$ and $\mathrm{CaTiO}_{3}$ phases (peak 6, as identified in Fig. 3) decrease in intensity, showing that these phases may have been decomposed by the excess of

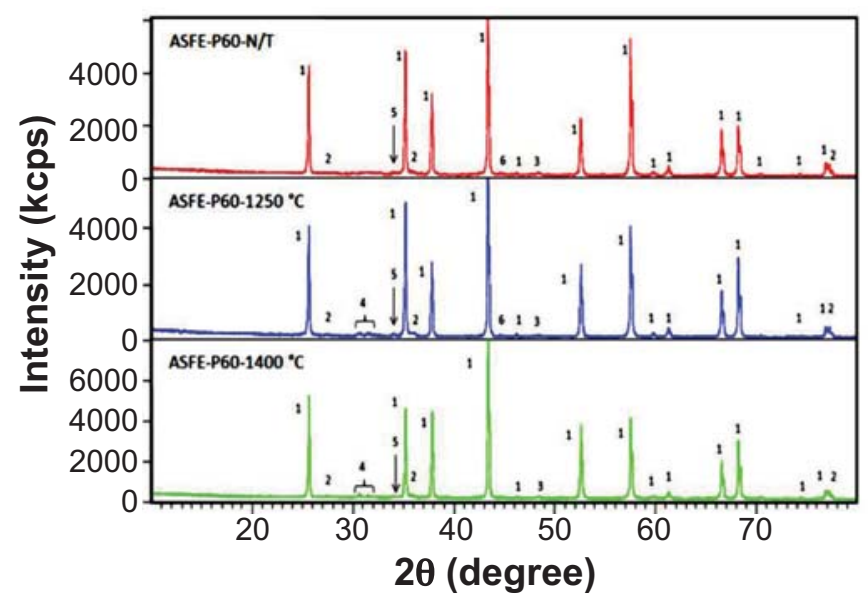

Figure 3: X-ray diffraction patterns of P60 grains of ASFE under conditions of non-heat-treated $(\mathrm{N} / \mathrm{T})$, heat treated at $1250{ }^{\circ} \mathrm{C}$ and heat treated at $1400{ }^{\circ} \mathrm{C}$, both for $14 \mathrm{~h}$. The meaning of the number from 1 to 6 is described in the text.

[Figura 3: Difratogramas de raios $X$ das amostras dos grãos P60 de ASFE, sem tratamento térmico (N/T), tratado a $1250^{\circ} \mathrm{C}$ e tratado a $1400^{\circ} \mathrm{C}$, por $14 \mathrm{~h}$. O significado dos números 1 a 6 está descrito no texto.] 
temperature during the heat treatment. In addition, it is also noticeable the possible $\mathrm{Ca}_{3} \mathrm{Al}_{2}\left(\mathrm{SiO}_{4}\right)_{3-\mathrm{x}}(\mathrm{OH})_{4 \mathrm{x}}$ phase (peak 5, as identified in Fig. 3). These phases are formed because of the elements present in bauxite.

After the first stage of this work, which consisted in defining the best temperature for the heat treatment, the next stage focused on performing tests under varied treatment times, from 14 to 7, and then $21 \mathrm{~h}$ (Fig. 4). For the materials presenting medium (ASFE) and low (ASF) contents of $\mathrm{TiO}_{2}, 7 \mathrm{~h}$ was enough time to reach a higher NFRI and the desired blue coloring requested by the market. The same does not occur to AR, though, which needs double the amount of time to reach an optimized condition. Besides the temperature and time of heat treatment, another variable was the atmospheric conditions during the heat treatment. Samples were treated in furnaces filled with atmospheric air and argon. For this last condition, some samples were encapsulated in quartz tubes containing argon to guarantee the best possible concentration of this gas. The results from this experiment are shown in Fig. 5. It is possible to observe that the non-heat-treated sample and the sample treated in an inert atmosphere present little difference if compared

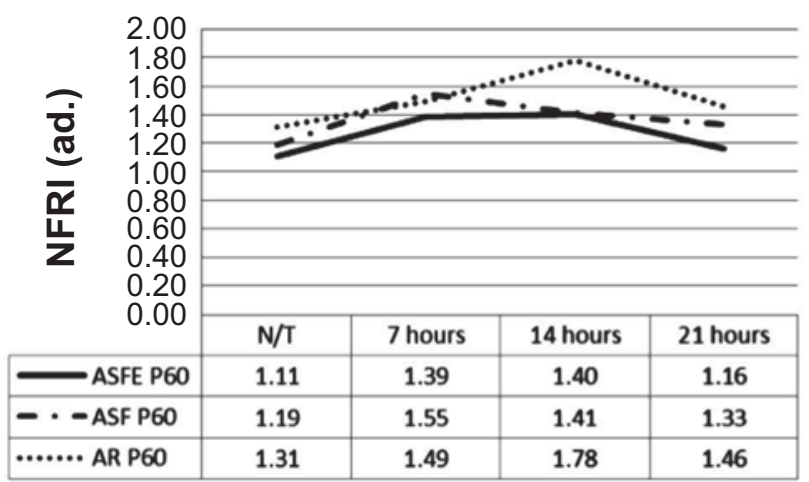

Figure 4: Normalized fracture resistance index of the P60 grains of ASFE, ASF, and AR, at $1250{ }^{\circ} \mathrm{C}$, varying the heat treatment duration from 7 to $14 \mathrm{~h}$, then to $21 \mathrm{~h}$. "N/T" means "non heat treated".

[Figura 4: Índice de resistência a fratura normalizado para os grãos P60 dos materiais ASFE, ASF e AR a $1250^{\circ} \mathrm{C}$ variando-se o tempo de tratamento térmico, de 7, 14 e $21 \mathrm{~h}$. "N/T" quer dizer "não tratada termicamente".]

against each other. Nevertheless, the material treated in air presented a significant NFRI increase, showing that the presence of oxygen in the heat treatment has great influence on the final material.

The final stage of this work consisted of two fusions in a pilot furnace at Elfusa Research Centre, employing raw materials of superior purity to be able to establish which chemical elements are responsible for the blue coloring that followed the brown electro-fused alumina heat treatment. The employed raw materials are presented in Table IV. The adopted proportion for each raw material was based on the $\mathrm{TiO}_{2}$ content of ASFE because this material has a great importance in what regards its application. The following

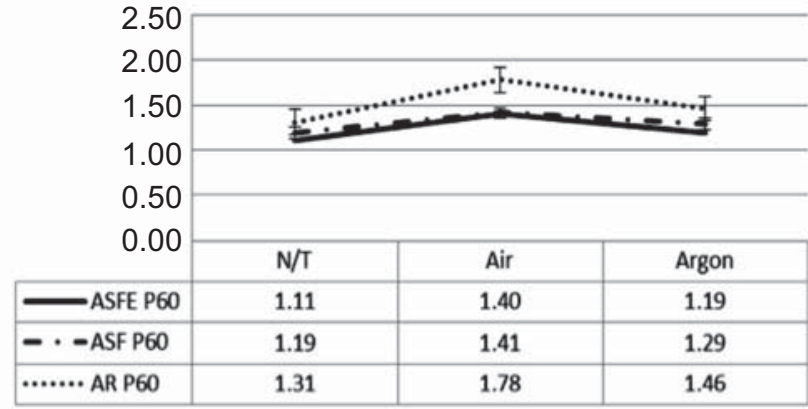

Figure 5: The influence of the heat treatment atmosphere under $1250{ }^{\circ} \mathrm{C}$, for $14 \mathrm{~h}$, on the normalized fracture resistance index of the P60 grains of ASFE, ASF, and AR.

[Figura 5: Influência da atmosfera de tratamento térmico a $1250^{\circ} \mathrm{C}$, por $14 \mathrm{~h}$, no indice de resistência a fratura normalizado para os grãos P60 dos materiais ASFE, ASF e AR.]

experiments were performed: a) a fusion experiment using APF calcined alumina, from ALCOA Alumínio S.A., and rutile, from INB - Indústrias Nucleares do Brasil as raw materials; b) the second fusion experiment in the same pilot furnace, employing the same raw materials as listed in the above item (a), adding to it hematite, from Bentomak. The results from this stage can be found in Figs. 6 and 7. After the electro-fusion of the two different compositions of items (a) and (b), the materials were classified in the designated P60 particle size, and then submitted to a heat treatment at $1250{ }^{\circ} \mathrm{C}$, for $14 \mathrm{~h}$, in air. By analyzing Fig. 6 results, it is possible to conclude that the heat treatment on the electrofused materials containing selected raw-materials had the effect of increasing the NFRI value. However, in the case of the material containing alumina and rutile only, despite the fact that the NFRI value increased after the heat treatment, the white coloring appeared, which is not a desired feature

Table IV - Chemical composition (in wt\%) of the raw materials used for the electro-fusion of the material of higher chemical control. "Others" are impurities which vary according to the presented raw material.

[Tabela IV - Composição química (\%p) das matérias-primas utilizadas na eletrofusão dos materiais com alto controle químico. "Outros" são impurezas que variam de acordo com a matéria-prima apresentada.]

\begin{tabular}{lccccc}
\hline Raw-materials & $\mathrm{Al}_{2} \mathrm{O}_{3}$ & $\mathrm{TiO}_{2}$ & $\mathrm{SiO}_{2}$ & $\mathrm{Fe}_{2} \mathrm{O}_{3}$ & Others \\
\hline $\begin{array}{l}\text { APF calcined } \\
\text { alumina }\end{array}$ & 99.59 & - & - & 0.01 & 0.40 \\
Rutile & 0.90 & 97.80 & 0.20 & 0.10 & 1.00 \\
Hematite & 0.77 & 0.12 & 0.95 & 98.16 & - \\
\hline
\end{tabular}

required by the abrasive market, as it can be observed in Fig. 7 . Nevertheless, by adding hematite (the material containing alumina, rutile, and hematite), the blue coloring appears, as it can also be observed in Fig. 7.

Therefore, it is possible to conclude that the change in the material's coloring is not related to the formation of $\mathrm{Al}_{2} \mathrm{TiO}_{5}$. 




Figure 6: Comparative results of NFRI for P60 grains of ASFE, the material made of alumina and rutile only, and the material made of alumina, rutile and hematite. ASFE was the reference material. The table presents the results of non-heat-treated materials $(\mathrm{N} / \mathrm{T})$, and the ones that have gone through the heat treatment at $1250{ }^{\circ} \mathrm{C}$, for $14 \mathrm{~h}$, in air.

[Figura 6: Resultados comparativos de NFRI para o ASFE com grão P60, o material feito com apenas alumina e rutilo e o material feito com alumina, rutilo e hematita. O próprio material ASFE serviu de referência. Apresentam-se os resultados para as condições sem tratamento térmico (N/T) e com tratamento térmico de $1250^{\circ} \mathrm{C}$, por $14 \mathrm{~h}$, ao ar.]

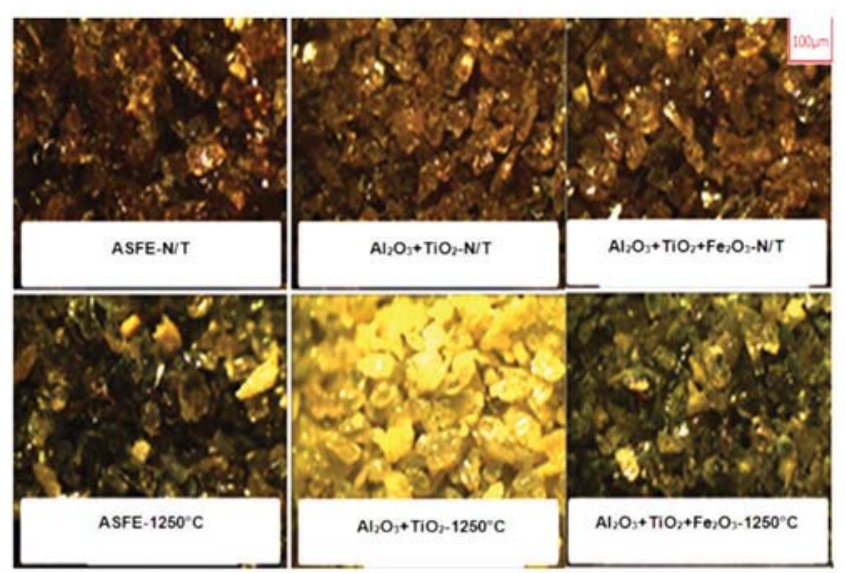

Figure 7: Stereomicroscope images of P60 grains of ASFE, the material manufactured with alumina and rutile only, and material formed by alumina, rutile, and hematite. The images show the results for non-heat-treated materials $(\mathrm{N} / \mathrm{T})$ and heat-treated ones at $1250^{\circ} \mathrm{C}$, for $14 \mathrm{~h}$ in air.

[Figura 7: Imagens de estéreo-microscopia dos grãos P60 de ASFE, do material feito com apenas alumina e rutilo e do material com alumina, rutilo e hematita. São mostradas as condições de sem tratamento térmico $(N / T)$ e tratamento a $1250{ }^{\circ} \mathrm{C}$ por 14 h ao ar.]

Instead, it is related to the same phenomenon of electron transition justifying the blue sapphire coloring. In sapphire, corundum $\left(\mathrm{Al}_{2} \mathrm{O}_{3}\right)$ is doped with $\mathrm{Fe}$ and Ti impurities. These chemical elements may present the following valences: $\mathrm{Fe}^{2+}, \mathrm{Fe}^{3+}, \mathrm{Ti}^{3+}$, and $\mathrm{Ti}^{4+}$. Depending on their concentrations, partial pressure of $\mathrm{O}_{2}$, and temperature at which sapphire is formed, $\mathrm{Fe}^{2+}$ and $\mathrm{Ti}^{4+}$ replace two ions of $\mathrm{Al}^{3+}$, neighbors in the $\mathrm{Al}_{2} \mathrm{O}_{3}$. A wide absorption band is formed on the edge of the red part of the visible spectrum, causing the blue coloring effect on the crystal. There is transference of electrons from $\mathrm{Fe}^{2+}$ to $\mathrm{Ti}^{4+}$, converting them into $\mathrm{Fe}^{3+}$ and $\mathrm{Ti}^{3+}[11,12]$. Hematite $\left(\mathrm{Fe}_{2} \mathrm{O}_{3}\right)$ presents two iron and three oxygen ions on each molecule. To balance the valence of the three oxygen anions (-6), hematite must be composed by two ions of $\mathrm{Fe}^{3+}$. Magnetite $\left(\mathrm{Fe}_{3} \mathrm{O}_{4}\right)$, on the other hand, contains three ions of iron, and four of oxygen within its formula. Considering this, to be able to find a balance between the valences of four oxygen anions (-8), magnetite must be composed of two ions of $\mathrm{Fe}^{3+}$ and one ion of $\mathrm{Fe}^{2+}$. Because the electro-fusion of the brown fused alumina needs a reducing atmosphere to reduce the $\mathrm{Fe}_{2} \mathrm{O}_{3}$ and $\mathrm{SiO}_{2}$ that are present in bauxite, it is expected that the added hematite may be converted into magnetite, creating the $\mathrm{Fe}^{2+}$ ion necessary for the transference of electrons to $\mathrm{Ti}^{4+}$, both in solution into alumina. Even if the reduction reaches wustite $(\mathrm{FeO})$, the iron valence in this phase will remain +2 . Based on Figs. 6 and 7 , it is possible to conclude that the coloring and NFRI value are not directly associated with each other. Despite the fact that the NFRI value of the material containing alumina and rutile only is as high as the one containing alumina, rutile and hematite, the first does not gain the blue coloring. Finally, the work herein has also carried out experiments using the same materials, but presented in finer particle size, such as P220, and coarser, such as P24. The results followed the same tendency of the P60 grain materials. However, for the finer material, P220, there was a sintering of grains at the temperature of $1400{ }^{\circ} \mathrm{C}$, which did not allow the NFRI characterization [13].

\section{CONCLUSION}

Considering the results found in the present work, it is clear that the temperature, time and atmospheric conditions used for the heat treatment of brown fused alumina to produce blue fired alumina must be under strict control for the success of such production. When $\mathrm{TiO}_{2}$ is a solute in $\mathrm{Al}_{2} \mathrm{O}_{3}$, it affects the normalized fracture resistance index, NFRI, of brown fused alumina. Under ideal conditions of oxidative heat treatment, the system favors a better dissolution of $\mathrm{TiO}_{2}$ and $\mathrm{Fe}_{2} \mathrm{O}_{3}$ in alumina and/or the necessary changes in valence of $\mathrm{Ti}$ and $\mathrm{Fe}$ ions. By performing the simultaneous fusion of alumina, rutile and iron oxide with low content of contaminants, it was possible to verify that, at $1250{ }^{\circ} \mathrm{C}$, the final material had an increase in NFRI value and, simultaneously, gained the blue coloring. On the other hand, using only alumina and rutile in the same proportions as the test using iron oxide, the final material presented an equivalent NFRI, but it developed a white coloring. Thus, the theory that justifies the blue coloring of the blue fired brown fused alumina is the same that explains sapphire's blue color and, therefore, necessitates the presence of $\mathrm{Fe}^{2+}$ and $\mathrm{Ti}^{4+}$ impurities in alumina. Because the ions of these metals may present two valence states, transitions through charge transference may occur, causing the brown fused alumina to change in color. In addition, the presence of oxygen during the heat treatment is crucial for the material to change from brown to blue. Finally, it is possible to conclude 
that the NFRI is strongly related to the content of titania in the brown fused alumina and that the coloring gained by the oxide after heat treatment is related to the valences of $\mathrm{Ti}$ and Fe ions. There is no direct correlation between the value of NFRI and the blue coloring.

\section{ACKNOWLEDGMENTS}

J. A. Rodrigues thanks CNPq for the Productivity in Research grants 307127/2013-3 and 303061/2009-0. Both authors thank Elfusa Geral de Eletrofusão for the support to carry out this work. The authors are also grateful to General Technical Manager Homer Foster from U.S. Electrofused Minerals, Inc., for discussions.

\section{REFERENCES}

[1] G.CH. Nussbaum, Rebolos e abrasivos, S. Paulo: Editora Jacomo, (1988) 503 p.

[2] J.L. Coes, Applied Mineralogy, In J.L. Coes, Abrasives: New York, Ed. by Frechette, Kirsch (1971).

[3] J.M. Jackson, P.J. Davim, Abrasives tools and bonding systems machining with abrasives, In J.M. Jackson, P. J. Davim, Machining with abrasives. New York: Editora Springer (2011) 1-72.

[3] P. Bonadia, "Aluminas eletrofundidas: desenvolvimento de processo e produto", Master degree dissertation in Materials Engineering, Universidade Federal de S. Carlos, S. Carlos (2002) 172 p.

[4] L.R.V. Constantino, K. Araki, D.O. Silva, W. Oliveira, "Preparação de compostos de alumínio a partir da bauxita: considerações sobre alguns aspectos envolvidos em um experimento didático", Química Nova 25, 3 (2002) 490-498. [5] T. Korim, "Effect of $\mathrm{Mg}^{2+}$ - and $\mathrm{Fe}^{2+}$ - ions on formation mechanism of aluminium titanate", Ceram. Int. 35 (2009) 1671-1675.

[6] R.D. Skala, D. Li, I.M. Low, "Diffraction, structure and phase stability studies on aluminum titanate", J. Eur. Ceram. Soc. 29 (2009) 67-75.

[7] American National Standards Institute, ANSI B74.182014, "For Grading of Certain Abrasive Grain on Coated Abrasive Material", Ohio (2014).

[8] American National Standard Institute, ANSI B74.8-1987 (R2007), "Recommended practice for Ball Mill Test for Friability of Abrasive Grain", Cleveland (2007).

[9] Federation of the European Producers of Abrasives, FEPA 44-1:2006(en), "Grains of fused aluminum oxide, silicon carbide and other abrasive materials: Determination of bulk density", Paris (2006).

[10] American Society for Testing and Materials, ASTM C135-96, "True Specific Gravity of Refractory Materials by Water Immersion”, (Reapproved 2003) West Conshohocken (2004).

[11] K. Nassau, The physics and chemistry of color: fifteen causes of color, N. Y., Wiley (1983) 504 pages.

[12] Y.-M. Chiang, D.P. Birnie III, W.D. Kingery, Physical Ceramics: Principles for Ceramic Science and Engineering, John Wiley \& Sons, N. Y. (1997) p. 135.

[13] R.E. Passos, "Compreendendo a influência da titânia no processamento da alumina eletrofundida marrom e sua caracterização para aplicações abrasivas", Master degree dissertation in Materials Science and Engineering, Universidade Federal de S. Carlos, S. Paulo (2014) 138 p.

(Rec. 03/08/2015, Rev. 03/11/2015, Ac. 14/12/2015) 